\title{
Art and Craft of Old Oyo: It's Manifestation in the Present Oyo
}

\author{
Moses Akintunde Akintonde and Margaret Olugbemisola Areo \\ Department of Fine and Applied Arts, Ladoke Akintola University of Technology, \\ P. M. B 4000, Ogbomoso, Nigeria
}

\begin{abstract}
The wealth of the Old Oyo Empire apparently provided good platform for art and craft to thrive in the metropolis. However, at the collapse of Oyo in early eighteen century, and the subsequent relocation of the capital to the present Oyo, art practice amongst other traditions in the town suffered a great decline, For instance, only little traces of the ancient art reported by European missionary were recorded. For this reason scholarship on the art of Old Oyo and the extant arts are invariably lean. With the position of Old Oyo, being a virile art centre in the ancient time, and the continual practice of art in the present time, a study of the art is therefore necessary if a comprehensive Yoruba art historical record would be achieved. This study examined the origin and history of Old Oyo which was observed as a factor which propelled art creativity in the Oyo metropolis. Art types and the general practice were studied. The ingenious creativity among the ancient Oyo artists was also discussed. A comparative study of the ancient and the extant arts of Oyo were also made to verify a probable continuum in the old and the new arts. The study apparently observed some resemblance in the art practices of the two cultures. It also noted that the great versatility and vitality of Old Oyo art and craft were above the extant Oyo art practice.
\end{abstract}

Keywords: Art, Craft, Oyo, Old Oyo, Oranyan

\section{INTRODUCTION}

The history of Oyo appears to be textural indices of the Yoruba sophistry in some respects. Perhaps it is safe to say; while the reflection or mimeses of the Yoruba traditional religion and socio-political engagement relied on Ife prototype or a cast of the same mould, Oyo appeared to create a separates structure peculiar to the empire (Kalilu, 2013:26-37). This structure was coveted by her neighbours and the vassal slates. Hence the aphorism; Ajisebi Oyo laari, Oyo ki ise bi enikankan (One only found people imitating the Oyo, Oyo never copy anybody).

The origin and history of Oyo is an extensive, complex historical discuss that can only be attempted in Art historical study like this. For example, Oyo as a language, spoken by large sub-groups of Yoruba or as a people who occupies large geographical area in the South West of Nigeria, are even more complex in contemplation. Scholars have already treated this issue to some appreciable level (Fadipe, 2012: 29-31). Their contribution nonetheless indicated that Oyo is a central figure among the Yoruba, in cultural history. Oyo appears to have been the first, to be called Yariiba (Yoruba) by the Northern Hausa elements (Fadipe, 2012: 3031). The name however was extended to various provinces of Oyo. Before the name was centrally used for all the people of Oduduwa (the progenitor of the Yoruba) descent; the sub-ethnic groups were known by each groups name such as: Ijesa, Ife, Ekiti, Awori, Ijebu, Ondo etcetera. During the slave trade they were sometime referred to as $A k u$ (Paul Hair, 1696:79-82, Fadipe 2012: 29) because of the manner of their greetings in Sierra Leone which is always prefixed with Aku, aku-osan, aku-ise, aku-iyaleta etcetera. Sometime, they were called lukumi, (olukumu) meaning, my friend; a term commonly used by the Ife, Ijesa, and Ekiti to call their acquaintance in place of personal names.

Be that as it may, according to oral tradition, Oyo was founded in the fourteen century by Oranyan (Fadipe, 2012: 33-34) a direct son of Oduduwa, the first King (Ooni) of Ife, Oranyan was said to be the youngest of the Oduduwa seven children. He was a valiant warrior. He was said to have reigned as king in IleIfe before he established Oyo (Johnson, 1921:124). Oyo or Old Oyo was located North-West of Ile-Ife (Atanda 1980:11) close to Nupe and Borgu. The Kingdom later grew to empire. After the death of Oranmiyan, many powerful kings reigned. Some of them are: Ajaka, Sango, Orompoto and Atiba. They expanded the Kingdom and instituted a unique political structure. At the early period, Oyo had to contend with the menace of Nupe and Borgu attacks (Atanda, 1980:11). The capital had to move from Old Oyo to Igboho as a result of the attacks in early sixteen century (Atanda, 1980:11). Oyo later recovered and vanquished the Nupe in 1625 (Encyclopedia Britannica) as well as Borgu forcing them to pay tributes annually (Atanda, 1980:11). During the empire wars of expansion, Dahomey (now Republic of Benin) fell to the superior cavalry borne military might of Oyo (Encyclopedia Britannica). At the apex of her power, the Ijaye, Egba, Egbado, Popo Sabe and Ketu were under the authority of Oyo by early eighteen century (Atanda, 1980:12). However, the empire collapsed as a result of 
lost of concentration caused by internal political wrangling which weakened the central government. The vassal states later took advantage of this and rebelled against the Oyo authority. For instance, the Nupe and Borgu attacked the empire and defeated Oyo. Dahomey in a series of attacks against Oyo eventually, defeated Oyo before the total sack of the empire came in the nineteen century by the Fulani jihadist (Fadipe, 2012:42).

Nonetheless, the Oyo were very proud of their military strength and unique socio political structures. This feat they referred to as: alara, Oyo mara ju ara oko lo (the owner of creative force, Oyo who knows creativity more than people of the less city). Never was any Oyo generation relapsed in ara- the factor of creative essence. From their primordial time to the present age, Oyo is awesome in creative force in all ramifications.

The feat performed in production and use of art in the Old Oyo was probably unparalleled by other Yoruba Kingdoms. Yet it is said that Africa is greatly endowed in art, but no other ethnics group is as prolific in art as the Yoruba (Willelt, 1965:n.p); Oyo was however in the fore front. But giving the vicissitude of time, occasioned by series of wars fought by Oyo and the counter wars against the empire between eighteen and the nineteen centuries which later left the Old Oyo in ruins, the art as well as other socio-political sectors were greatly affected. So devastating was the effect of the wars on the art that Clapperton, the missionary, who visited the place shortly after the fall of Old Oyo hardly saw the traces of the exquisite art that once adorned the palace of Alafin (Fadipe, 2012:41-42). This factor, invariably affected the art historical discuss on Oyo art (Kalilu 2013:19). However the good quality of Oyo art can be articulated, based on the little evidence gleaned from the remains of the Old Oyo, the oral historical account on the proficiency in art and preponderant use, and the continual art practice in the modern Oyo.

However, the Oyo art and craft is rich in type and depth of practice. Much conscious effort has not been made on a proper investigation of the Old Oyo art and the new. Little is still known about the Old Oyo art. Although many archeological investigations of the Old Oyo site have been carried out, yet the results from the site were not enough to give graphical details of Old Oyo art. The comprehensive study made on Oyo art by Kalilu (1992a) is yet to be published for the public to benefit. He has however, published about four well researched articles on Oyo art based on art historic theory.

This study, has therefore attempted a comparative studies of the Old Oyo art and the present one with a view to under-score a probable continuum in the two art traditions. In this study, the geographical spread of the people, Oyo sub-ethnic group of the Yoruba both in language and in culture is not our concern. Rather, the emphasis of the study rest mainly on the art in the metropolitan Oyo, where the seat of government of Oyo Empire resided as from fourteen century. A brief reference into origin, religion and socio-political and economy of the metropolis were made, with the aim to identifying and assessing the factors of art and craft development and the corresponding continuum in the modern Oyo. Significantly, the study is articulated to evaluate the development of art and craft in the present day Oyo. In doing this, the outcome probably may inspire conscious effort in the development of the art and craft of Oyo towards self reliance of individual artists, tourism drive and glorification of the town, the Yoruba and Nigeria in general. However scholarship on Oyo art is still very lean, comprehensive work on the art of Oyo was carried out by Ojo (1990) in the use of oral tradition to attempt historiography of Oyo, Kalilu's (1991, 1992a, 1992b:49-63, 1994:18-14, 1995a:11-19, 1995b:125-160 and 2013) are wholist and extensive works as well as Aremu (1998 and 2002) are just unfolding, a follow up to these studies is the present work.

Moreover, Kalilu's (1992a) Ph.D. dissertation dwells entirely on Oyo art, her influence in Southwestern Nigeria and the neighbouring states, even across the Nigerian boarders, as far as Benin Republic and Togo. Kalilu lucidly discussed the magnificence of Oyo Empire; her religion, political expertise, formidable military formations and might, the opulence and social status among the Yoruba and even beyond, to as far as Alladah and Ouida states of Dahomey and Ewe (now Republic of Benin). He relied on account of missionaries such as Clapperton, Lander brothers and Clark who visited Old Oyo and his field investigation account. He unearthed and thoroughly discussed Oyo art in archetypes in chronology, provenance, form, style, themes, technique and function. His study on gourd carving in Oyo (Kalilu, 1991:99-108, 1994:18-42 and1995a:11-19) and the ones preceding (Kalilu, 1992b) leave us in no doubt that Oyo art style is unique and sublime.

Aremu's (1998 and 2002) studies on the traditional carvers of Oyo descent are quite informative. Carvers' lineage were identified and succinctly discussed. In the study, form, individual style identities, material, thematic and morphology tendencies were discussed. Other studies, including the art evidence in Agbaje-Williams's (1983) archeological investigation of Old Oyo attested to the fact that the empire had been an important art centre since the ancient time. The fact that the art is still being practiced, in the town, today, with some degrees of reflection of the ancient Oyo art and craft in form, style, motif and themes, further lend credence to the high proficiency in the practice and lavish use of art and craft in the town. 


\section{Art And Craft In Old Oyo}

The traditional Yoruba religion requires art services in the pantheon of the Yoruba gods. As a result, elaborately carved wood sculpture, cast and wrought Iron, terracotta figurines pottery objects were used in the worship of the gods. At both communal and individual shrines and festivals, art were high in demand. Art in the leadership role were also abound; carefully modeled according to specification and dictates of different offices and hierarchy. The noble also enjoy ownership of certain type of art, while the commoner were not forbid to use art work. However, they were not to use bronze object which was the exclusive reserves of the King, Ogboni cult (earth god) and some other gods. Other art and craft items such as: gourd and calabash carving, mat weaving, basket weaving, cloth weaving, embroidery making, leather work, pot making among others were generally made for domestic purposes.

The wars of expansion and the resultant vastness of Old Oyo with its attendant mammoth population, complex political structure and successful administration and the secured environment invariably, might have influenced art boom in the city. It should be noted that Oyo opulence was as a result of her military success good administration and control of trans-Sahara trade route which runs from the North across the northern Yoruba, and proximally located around Old Oyo (Encyclopedia Britannia). The control of sea-port at Ajase in Port-novo, Badagry and later, Lagos where slave were shipped to Europe also contributed to economic strength of the Old Oyo (Encyclopedia Britannica). It was even reported that about 638,000 US dollars were paid annually by Dahomey to Oyo as tributes. The Nupe and Borgu at a time were also subjugated and made to pay tributes. Apart from these three kingdoms numerous other vassal states and provincial towns and villages as a matter of loyalty paid tributes to Oyo. As the state was rich, so were the people. Thus art objects were capriciously used by the state and her people

For instance, numerous veranda posts were reported to have been used as architectural accompaniment in the Old Oyo palace. R. W. Keay reported to have seen seven or eight of the veranda posts which have been miraculously saved from fire in the attack of the Old Oyo (Adepegba, 2007:18), while one hundred brass posts formally used in the verandas were reported by Clapperton to have been looted by Fulani army (Fadipe, 2012:41-42). Clapperton also reported to have seen wood carving veranda posts. They were expressed in military themes (Kalilu, 1995:125-142). The contents of the work include: procession of warriors and drummers as well as animals. The flock of artists into the town is also instructive of the abundant art commissions on ground for take. Are Lagbayi ara Ojunwon, an eighteen century wood carver was one of the numerous artist who practiced wood carving in Oyo. He was the progenitor of Abogunde wood carver lineage in Oyo (Abimbola 1990, Adepegba 1995:48, Adepegba 2007:23). Some of them practice their art in Ogbomoso, Iwo and Ede. There was also the Ona Ibuke wood carving lineage. In calabash carving, the exploit of Onirese is well known through oral tradition. Onirese was a well known traditional carver who firmly established himself as a prolific artist, shrewd in the art of calabash carving. Metal art was also extensively practiced in ancient Oyo. The abundance of iron ore around Oyo town in Isudunrin and Laagbe areas made iron smelting, wrought iron work and bronze casting profitable vocations in the town (William, 1973:144-14). The Oyo northern link also predisposed the supply of leather used for the production of puffs, hand fan, bag, purse and other leather items. The link also must have brought the diffusion of northern motifs in the designs and pattern of the Oyo leather work. These motifs were also employed in gourd and calabash carvings.

In the art practice, the general Yoruba style was operational in Old Oyo. However, Oyo actually developed a peculiar style. That notwithstanding, the Yoruba conventional style of head of a figure being a third or a quarter of the total proportion, which placed philosophical emphasis on the significance of human head; as both the spiritual control and the co-ordination centre of the human inner essence and his physical body was still practiced along other Yoruba aesthetic canon.

Originality and quality based art was strictly enforced in ancient Oyo. A royal contest recorded in an oral tradition well discussed by Opefeyitimi (1995:20-39) also attest to high quality control of standard in the Old Oyo art practice. This is evident in the following Oloje praise song:

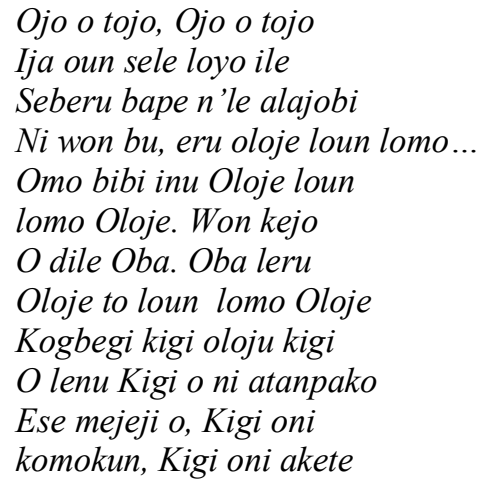


pempe lori oko.

Eru gbegi, igi oloju, igi o lenu...

Omo bibi are Oloje gbegi

Igi loju, Igi lenu, Igi latampako

Ese mejeji o. Igi ni Komokun

Igi lakete lori oko

Won ni omobibi Oloje niwo... (Opefeyitimi, 1995:20-39)

Days and days ago

There was a contention at Oyo metropolis

Slave that is well acquitted

With his master's house

Swear in the name of his clan

The slave of Oloje says he is a true child of Oloje...

The child of bowel of Oloje

Says he is the true child of Oloje

They took the matter to the house of the king.

The king says the slave of Oloje

Who says he is the child of Oloje

Should carve wood

Wood should have mouth

Wood should have toes of the two legs

Wood should have Adam's apple

Wood should have helmet atop penis

Slave carved wood

Wood did not have eyes...

The child of the bowel of itinerant Oloje

Carved wood

Wood had eyes

Wood had mouth

Wood had toes of the two legs

Wood had Adam's apple

Wood had helmet a top of penis

They say the child of the bowel of Oloje

You are ... (translation mine).

From the oral tradition, two carvers who were estranged based on professional rivalry were called to produce a wood carving figure. Specification and time frame were given. A body of jury was also constituted to assess the work of each artist. At the end of the exercise Omo bibi inu Oloje won. He complied with the Yoruba aesthetic indices such as stated by Abiodun, (1990:63-89) and Abiodun, Drewal and Pemberton III, (1991) dexterously to drive home his expertise in wood carving. Of course, it is expected that wood carving ingenuity will run in his blood, since he was a biological son of Oloje, in the Lagbayi wood carving lineage. A slave who only acquired wood carving skill through learning cannot be as good as those that knew the secret of the profession; because the Yoruba would not give the secret of their profession away to non lineage member under apprenticeship no matter how close the person may be to the lineage. This type of test connotatively was instructive of high competition among the Old Oyo artists.

So great is the fame of Oyo art in its propensity that it pervaded the fabrics of various oral traditions. For instance, in semiotic and language development, the Oyo art experience was brought to bear, in Yoruba idiomatic expression, proverbs and aphorism. An instance of this observation is portrayed by the following expression: Ilekun abogunde, (the door of Abogunde), strong and beautiful door. Abogunde, an adjectival noun, which describe type of door in real sense, was a shrewd Oyo wood carver. He was famous for his dexterity in door panel carving in the ancient Oyo. Up till the modern time, his fame still manifest across the various Yoruba sub-groups of Southwestern Nigeria, through the adoption of his name in Yoruba lexicon. Thus any door considered to be strong, beautiful and expensive is referred to as; Ilekun abogunde. Even, a less quality door is still hyperbolically referred to as Ilekun abogunde contextually in comical situation.

Today, the full strength of Old Oyo art may not be comprehensible enough due to the devastating military bombardment of Old Oyo from all fronts. But art critics and art historians could take solace in the following Yoruba proverbs, hinged on Oyo art practice: 


\section{Bonirese o fingba mo \\ Eyi to ti fin sile o le parun}

If Onirese no longer carve calabash

The one he has made cannot go into extinction

Onirese in the statement in reference here; was a master artist in calabash carving vocation whose carving skill had reached a state of the art level. His products were acclaimed to be too numerous and wide spread such that they were metaphorically referred to as "indestructible". Unequivocally, the import of this proverb is normally used to portray individual person or group of patriotic people's and achievement. Denotatively, the statement also, refers to ingenious Oyo art in the ancient time.

\section{Art In The Modern Day Oyo}

It will be wrong to assume by inference that Oyo art died with the fall of the empire around 1833 (Fadipe, 2012:42). Though devastative and morbid, the sack of Oyo was only a temporary experience in the human development. Oyo came alive doggedly and occupied her position among the Yoruba. The cultural and the socio-political influence of the town never waned in the scheme of events in the post-independence Nigeria. The Alafin-Oranyan personified, is a great first class paramount ruler, whose authority, power and influence permeate and transcend Nigeria shores. Although the Islamic and Christian religions as well as western civilization have seriously affected traditional religion, yet Oyo remains a strong cultural town. All the full complements of traditional political structures in leadership and authority are still in place as in the ancient time. However, the dislocation of the empire, the relocation of the capital to the present Oyo town and the population shrinkage, drastic reduction in the area of political power coverage definitely decrease the hitherto profuse use of art as it was in Old Oyo when compared to the the extant town. It will be recalled that Kalilu (1995:125-142) stated that, about nine hundred and sixty carved posts were produced by Lagbayi during the reign of Alafin Abiodun. The oral tradition which Kalilu cited indicated that the carved posts were used for Alafin palace decoration. This of course would have improved the artist's proficiency iconography and iconology. The artist from Kalilu's explanation was also not restricted on the theme to work on. In this case, Lagbayi had good opportunity to stretch his creativity to the brim. Although there were carvings in the present palace of Oyo, certainly they are not as many as those used in the Old Oyo palace. The opportunities to demonstrate artistic creativity are not also given to the extant artists as in the ancient Oyo practice. It appears that display of wealth is the factor Oyo also used in intimidating their vassal states apart from military might. Art in various forms as used by the Old Oyo become easy mode of expressing the opulence of the empire physically. This idea is common among the ancient world powers. Powerful ancient states such as: Egypt, Rome, Florence and China were known in history to have displayed their wealth through lavish use of art.

Although, the political structure of Oyo, still remain the same as the ancient mode, the practice is not total. For this reason, the factors which motivate production of art work and creativity have reduced, at least in scope but not in intent. Comparatively, Oyo is not the only art centre in Nigeria affected by some shift in cultural values which probably resulted in decline in art production. Benin and Owo were also affected. But Benin particularly, was able to keep art production and creativity alive. For instance, the guild system in various art forms is still intact. The system is still being controlled from the palace. Although, art in the town as well as in many African cultures today are not produced in large scale for communal use as in the ancient time. But Benin has been able to organize the trade well, such that art connoisseurs and patrons can easily locate the artists for their needs in a place designated to the artists in the town. Idah brass work and Bida bead work are still richly being produced and well patronized. But Oyo art guild suffers huge setback for not being able to control the system presently. The system invariably, is not functioning. Yet there are still wood carving lineages, Onabuke, Arikende even the Abogunde wood carving lineages are still in Oyo. There are also the calabash carving, cloth weaving and black smiting lineages in Oyo, who are still practicing somehow, minimally. However, Western education and crave for quick money did not encourage offspring of the artists to take up the noble profession of their forebears. Rather, they preferred white collar job or easy money making ventures.

Indeed, the continuity of the old art in the extant one appears to be in the repository of ancient motifs the artists still choose from; themes to some extent also still reflect those of the ancient art, mainly for aesthetic purpose. Technique of art production is also the same in the use of material and tools. However, the introduction of new materials, tools and equipment and production processes as a result of advancement in science and technology only marked the difference. That notwithstanding, it is still possible to clearly gauge some continuity in both art cultures. For instance except in the area of jurisprudence in which the western format have taken substantial part from traditional authority, despite the modern civilization, the nascent art in Oyo continues to service the traditional institutions. Beaded crown, and staff, horse whisk bead work handle, and other paraphernalia of royal personage and the chieftain insignia of office, cult art objects are still being produced in 
Oyo. They are used by various traditional title holders. The liberalization of the use of art object of any medium by all citizens unlike the restriction placed on the use of bronze object by the commoner in the ancient time might have also expanded the production of metal art in the town.

Apart from the gourd and calabash carving that derived largely from the ancient motifs and techniques, modernity as well as advancement of science and technology seemed to have enforced new genre in form, style, themes the material and technique on the nascent art. Even modern day experience such as automobile, airplane, flora, fauna and calligraphic representation of various types were deployed into the design and production of calabash carvings (plate 1). The forms are expressed in realism. Occasionally, forms may be expressed in intense stylization but discernible. Linear and abstraction forms were also expressed (plate 2). The gourd and calabash carving are produced to be given as souvenir. Yemi Salaam a calabash carver located at Alaaka Market Ilora very close to Oyo claimed gourd and calabash are sometime customized for marriage, birthday, and retirement meritorious ceremony, assumption of new position and acquisition of property. This craft is sold far beyond Oyo. In fact some of the artists have even opened other studios in Osogbo, Ede, Ibadan, Lagos and other Yoruba town

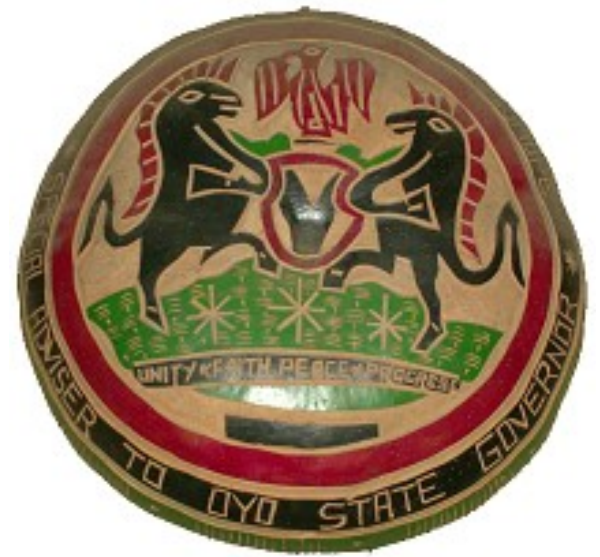

Plate 1

Contemporary carved gourd decorated with Nigeria's coat of arms motif and calligraphy in Oyo.

Photography by Segun O. Abiodun, 2010.

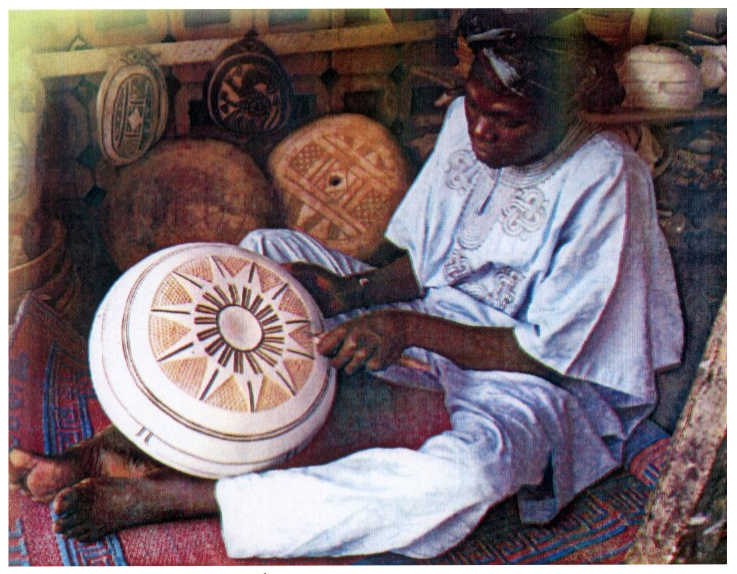

Plate 2

Calabash carver at work in Oyo.

Courtesy of G. B. Aremu (ed), 2012.

Decorative leather work, such as puff and hand fan bearing colourful motifs representation of Nigeria's coat of arms, maps of Nigeria and Africa, royal insignia of office among other themes combined with linear motifs and calligraphy are mass produced with both stitching and applique methods (plate 3). Small talking drum made for decoration, are also part of the craft objects produced in Oyo. These various craft items are often sold to craft merchant from Abuja, Lagos, Ibadan, Port-Harcourt and other cities. The craft objects are usually sold in departmental store at the gift items corner, airports and hotel pavilions. Various types of Bata drum leather work-band as well as gangan, gudugudu among other bands are also exquisitely decorated in linear motifs (plates 4 and 5).

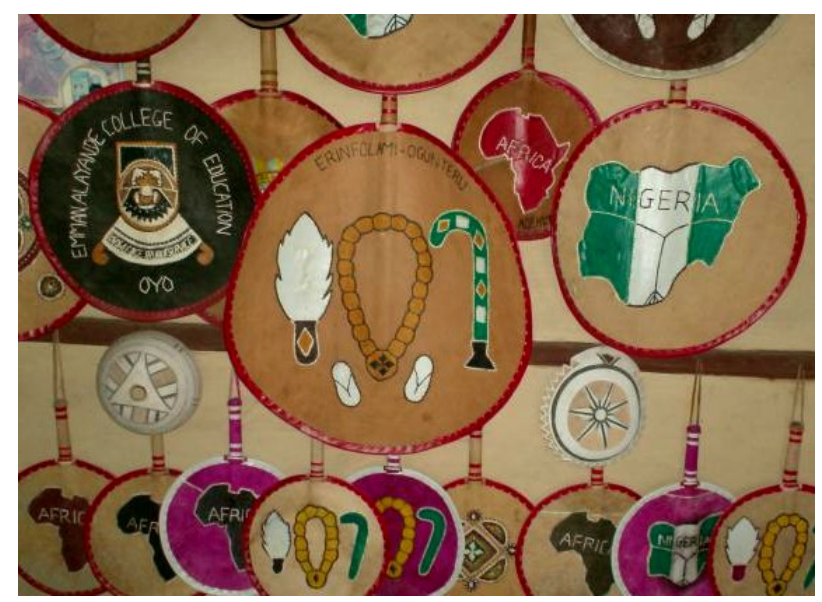

Plate 3

Contemporary leather works decorated with maps of Nigeria and Africa, royal insignia of office and calligraphy. Photography by Segun O. Abiodun, 2010. 


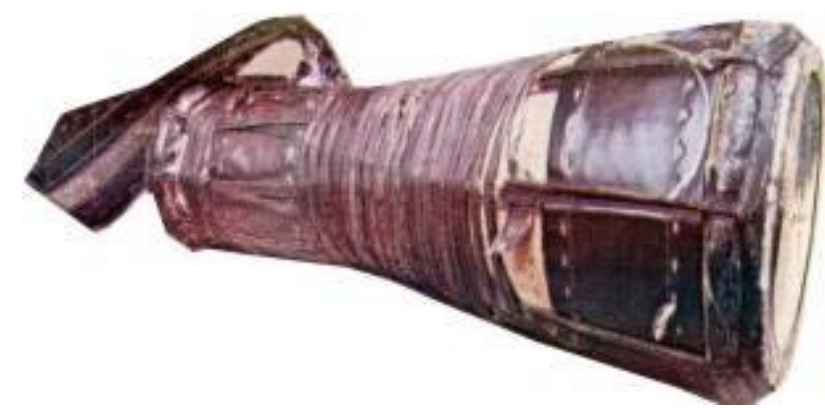

Plate 4

Contemporary bata drum leather work-band with linear motif in Oyo.

Courtesy of G. B. Aremu (ed), 2012.

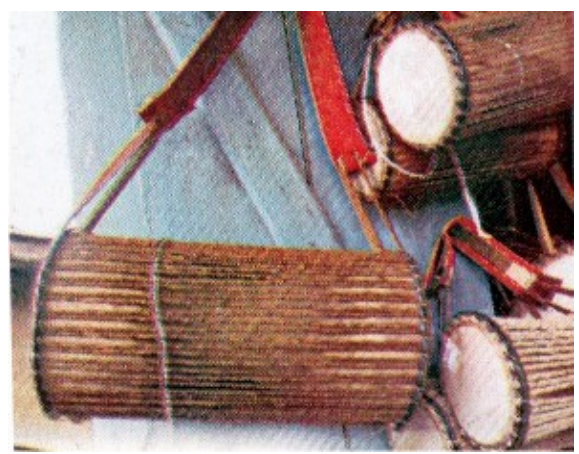

Plate 5

Contemporary talking drum leather work-band with linear motif in Oyo.

Courtesy of G. B. Aremu (ed), 2012.

Traditional wood carving is still ongoing in Oyo. Carvers continue to carve items such as ere ibeji (twin wood statuette) Opon ifa, (ifa tray) and other religious and decorative sculpture objects (plates 6, 7 and 8). Jide Odekunle one of the few carvers remaining like other still produce wood sculpture purposefully made for decoration for sale (pate 9). Carvers are also usually commissioned to produce wood sculpture with specification by their patrons. Forms, style and technique of wood carving still draw largely from traditional convention; aside from the introduction of some modern tools which are still used side by side with locally made types. Traditional themes are still largely expressed by the wood carvers. Equestrian figure and Yoruba traditional anecdote are still part of the extant wood carving composition. The horse rider or the warriors often depicted are not representation or record of any war. Compositions in such form are basically made on aesthetic reason alone. Abstract forms in modern art orientation are also expressed particularly by artists who have formal education such as Odewale.

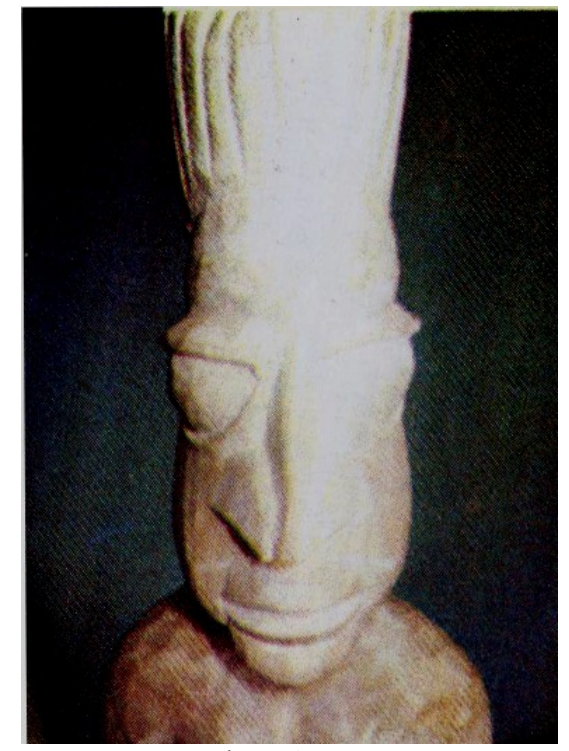

Plate 6

Contemporary wood carving

in Oyo.

Courtesy of G. B. Aremu (ed), 2012.

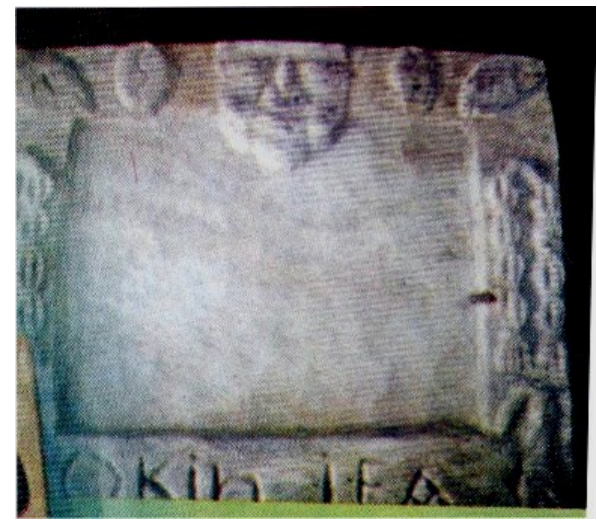

Plate 7

One of the contemporary carved

Okin Ifa (Ifa tray) in Oyo.

Courtesy of G. B. Aremu (ed), 2012. 


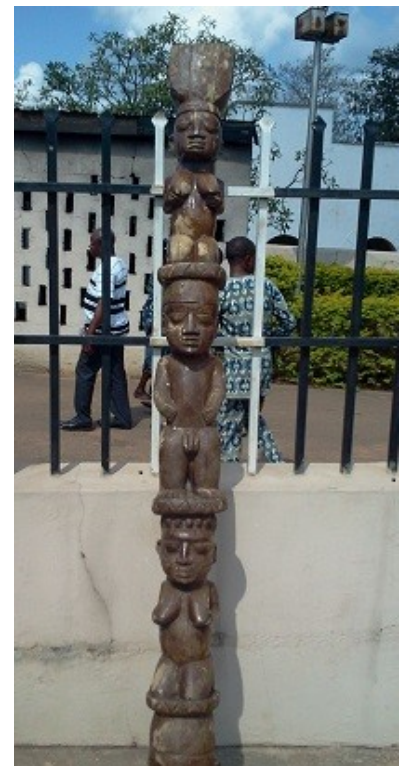

Plate 8

One of the contemporary carved posts in Alaafin's Palace, Oyo.

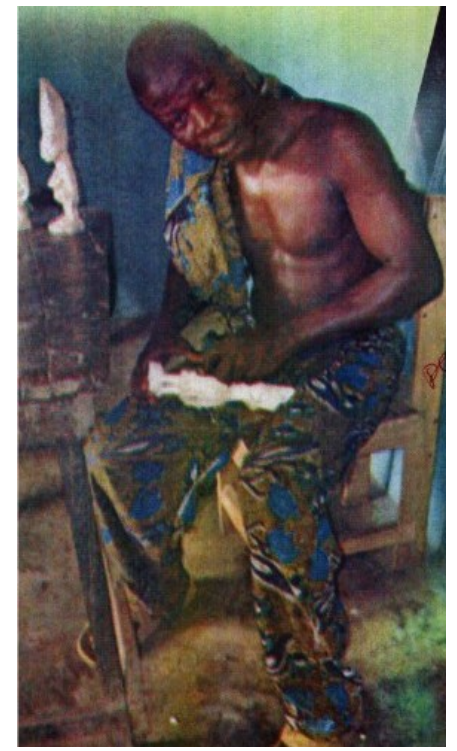

Plate 9

Wood carver at work in Oyo.

Courtesy of G. B. Aremu (ed), 2012.

Photography by Moses A. Akintonde, 2012.

The location of tertiary institutions that offers Fine Art as field of specialization has also helped the growth of art in Oyo. Two institutions in the town; Emmanuel Alayande College of Education and Federal College of Education (Special), Oyo, with seasoned art lecturers such as; Gabriel Bolarinwa Aremu, Amos Areo (both now retired), Adebowale who transferred his service to another art institution, Odewale and Tiri Oladimeji respectively have helped the course of art in various ways in the town. Both art workshop centres and formal art school in the town appeared to have instituted a symbiotic relationship. Both derived inspiration from each other on the conscious and subconscious levels. They have also mutually and separately contributed immensely in the human development in nation building, particularly in Oyo and generally in the country.

Ceramic art in Emmanuel Alayande College of Education have been well developed. Evidence of proficiency in the art lies in their giant segmented pots, typical of lfe Art School where Amos Areo, the specialist in ceramics was trained (plate 10). Forms of the pots are traditional in morphology; they are conical and spherical in shapes with flared and inverted rims. Motifs are graphical in representation and expressions. Motifs are derived from traditional religion genre and rendered in contemporary style. The presence of a ceramic courtyard industry known as Dapo Art Gallery runs by Dapo Eyinade also provide additional didactic

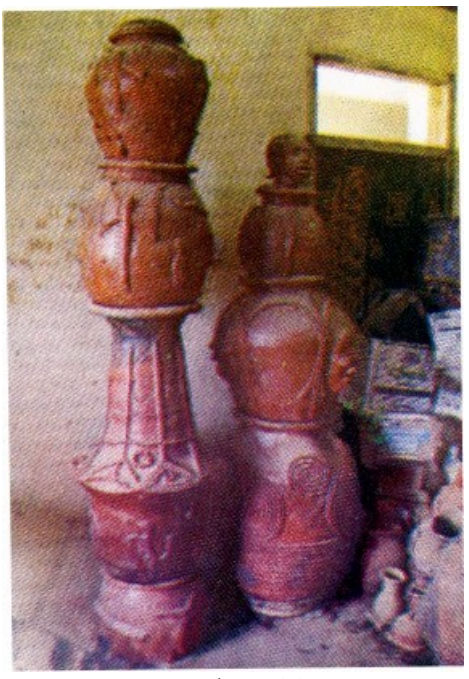

Plate 10

Giant segmented pots at Emmanuel Alayande College of Education, Oyo. Courtesy of G. B. Aremu (ed), 2012

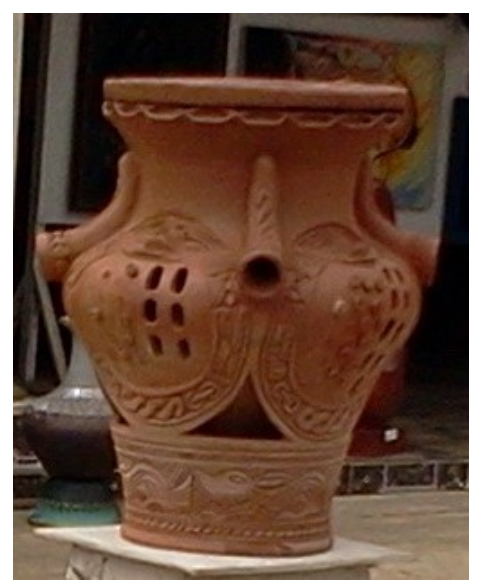

Plate 11

Decorative pot with Opon Ifa motif made by

Dapo Eyinade of Dapo Art Gallery, Oyo.

Photography by Moses A. Akintonde, 2012. 
avenue for students of art in Emmanuel Alayande, and Federal College of Education (Special), Oyo. Other art lovers in the town also have the opportunity to appreciate industrial ceramic production processes in Dapo Art Gallery (plate 11).

Textile art is still practiced in Oyo in their various forms and methods. Although Areo and Kalilu (2013:360) observed that traditional Adire centres are less concentrated in Oyo in this recent time, however, textile as exquisitely expressed with traditional motifs in tie-dye, batik and applique combined printing are still produced by workshop centres and in the two art schools. Painting, graphics and sculpture are also well studied in the two institutions and practiced by formal and informal trained artists in the town.

Art School such as Obafemi Awolowo University, Ile-Ife, Institutes of African Studies, University of Ibadan and Ladoke Akintola University of technology, Ogbomoso has also been sources of influence for the youths of the town who are interested to take art as career. These also have helped the development of art in the town. For example, Samson T. K. and Salawu Ibrahim, both who studied art in Obafemi Awolowo University, Ile-Ife are the artist who produced the statue of Are Ona Kakanfo Oyabi erected at Akesan market in Oyo and Sekere loba njo erected infront of Alafin's Palace, Oyo respectively (plates 13 and 14).

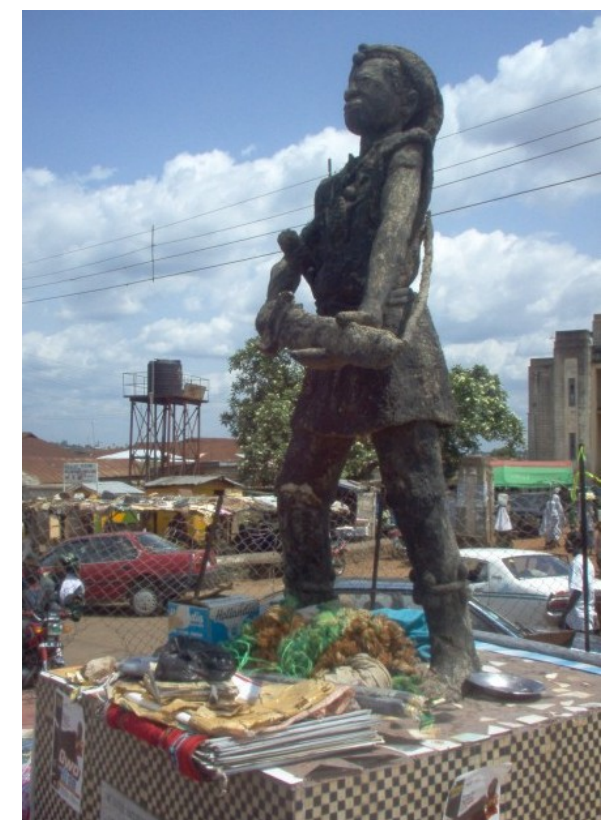

Plate 12

Are Ona KakanfoOyabi made by Samson T. K. in 1999 erected at Atiba, Oyo.

Photography by Moses A. Akintonde, 2008.

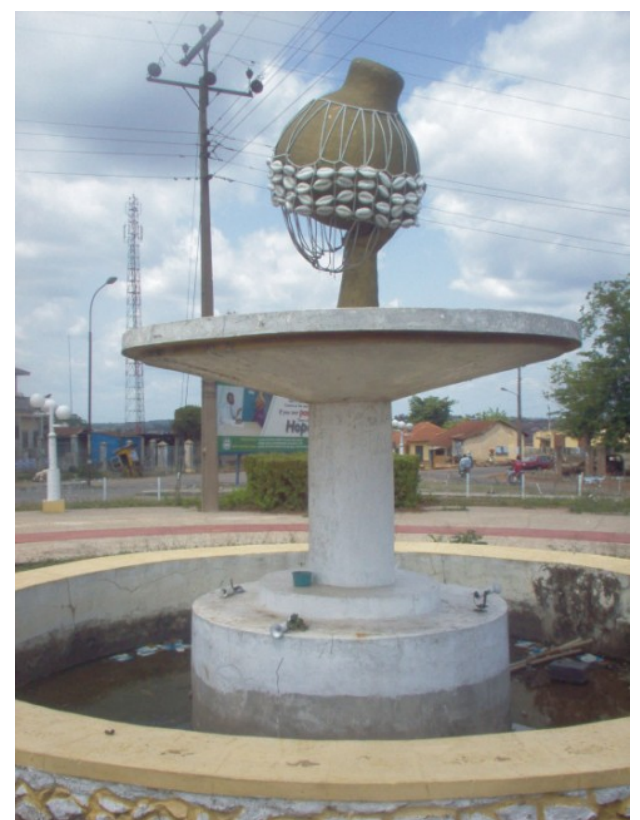

Plate 11

Sekere lo'ba njo made by Salawu Ibrahim in 2004 erected infront of Alaafin Palace, Oyo.

Photography by Moses A. Akintonde, 2008.

\section{CONCLUSION}

Oranyan, the founder of the great Oyo Empire was an embodiment of power, authority and statesmanship. His military power and shrewd leadership was unique and unmatched by other ancient Yoruba Kingdoms. This virtue he bequeathed to Oyo and the entire Yoruba race. It appears that his military audacity and shrewdness in administration were emulated by the subsequent Alafin and strictly observed as unflinching power in statesmanship. Oyo military was unique in organization and highly formidable. Equipped with calvary and strong willed army, Oyo's war of expansion became astonishing. The Borgu and Nupe to the north were subjugated while on the west the Dahomey (now Republic of Benin) were vanquished and kept under the Oyo surveillance for a long time. Many Yoruba towns also became taxpaying vassal states to Oyo.

As a result of constant successful military campaigns, Oyo soon became urbanized and wealthy. The opulence appears to have provided good quality life for the citizenry as a result of which art flourished greatly. Apart from the extensive use of art objects in the traditional religion, leadership role, and household utilitarian objects, art objects were also lavishly used for aesthetic purposes in the Oyo metropolis. Art vocations in calabash and gourd carving, leather work, cloth weaving and dying, pottery, wood carving, iron smelting and wrought iron work and bronze casting were greatly practiced. Art productions in Old Oyo were unique in types and form. Good quality standard was also enforced. The ever available commission, for the artists, encouraged establishment of individual art lineages in Oyo.

The modern day Oyo has also benefitted from the ancient Oyo art prowess. Although the fall of Oyo in the nineteen century greatly affected and threatened the practice of art in the city, yet some artists appeared to 
have weathered the storm and continue their art vocation in Oyo and some other Yoruba towns. This is evident in the volume of craft objects still being produced, in the town while the current craft objects and traditional wood carving still reflected the motif, form, style and the expertise of the ancient Oyo art to some extents; evidence of western culture have also greatly influenced conceptualization, expression of forms as well as the use of imported materials, tools and equipment. Patronage for craft objects in the town is still fairly large. However off short of craft workshops of Oyo origin in other Southwest of Nigeria towns seemed to have limited craft work patronage in Oyo. Except for the presence and influence of two art institutions in the city, population of the main Oyo artists have also reduced. This may be premised on the sharp fall in demand of art objects in the traditional Yoruba religion, which has been affected by the two alien religions. The present poor economy of the country also affected art patronage. Nonetheless, the factor of ara (creative ingenuity) reigns supreme, in the extant art of Oyo reminiscence of Old Oyo art even amidst the contemporary advancement in science and technology.

\section{REFERENCES}

[1] N. A. Fadipe, The sociology of the Yoruba, (Ibadan, Ibadan University Press, 2012)

[2] P. Hair, An Ijebu man in Paris, 1839, Nigeria Magazine, No. 68, 1962, 79-82.

[3] S. Johnson, The History of the Yorubas, (Lagos, CMS Bookshops, 1921)

[4] J. A. Atanda, An Introduction to Yoruba History, (Ibadan, Ibadan University Press, 1980)

[5] Encyclopedia Britannica, Oyo Empire [www.britannica.com/oyo-empire].

[6] F. Willett, "Introduction" in The Sculpture of Western Nigeria, 1965.

[7] R. O. Rom Kalilu, Old Oyo in West African Art, Ph.D. thesis, University of Ibadan, 1992a.

[8] R. O. Rom Kalilu, Between tradition and record: A search for the legendary wood carvers of Old Oyo, Ufahamu XX (11), 1992b, 49-63.

[9] J. R. O. Ojo, The praise poetry of Lagbayi Olojowon, eponymous ancestor of Yoruba wood carvers: An aspect of the relationship between verbal and visual arts, A Rockeffeller Lecture Delivered at the Centre for Cultural Studies, Rice University, Houston, Texas, 1990.

[10] Kalilu R.O. Rom, The origin of gourd carving among the Yoruba and the implied whereabouts of the first domicile of the Oyo rulers. The Nigerian Field, 56, 1991, 99-108.

[11] R. O. Rom Kalilu, Crisis in African art studies: Yoruba gourd carving and the need for historical concern in art history, in R. O. Rom Kalilu (ed), African art: Definition, forms and styles (Ogbomoso, Ladoke Akintola University of Technology, 1994) 18-42.

[12] R. O. Rom Kalilu, Fluxion and Responses: Yoruba Art as Expression of Power in R. O Rom Kalilu (ed), Power of Expression and Expression of Power in Yoruba Art (Lagos, Bidsol and Associates, 1995a) 11-19.

[13] R. O. Rom Kalilu, Imagery of martial Power: Some comments on the provenance of the themes of the Procession warriors, in R. O Rom Kalilu (ed), Power of Expression and Expression of Power in Yoruba Art (Lagos, Bidsol and Associates, 1995b) 124-160.

[14] R. O. Rom. Kalilu, Art from art for art: Conceptualising existence in the space of the visual arts (10th LAUTECH Inaugural Lecture Series), (Ogbomoso, Nigeria: Ladoke Akintonde University of Technology, 2013).

[15] G. B. Aremu, Wood carving in Oyo: A test case of the use of oral literature as historical evidence, m.a. diss., University of Ibadan, 1988 .

[16] G. B. Aremu, Abogunde carvers' lineage among the Yoruba, Ph.D. thesis, University of Ibadan, 2002.

[17] B. Agbaje-Williams, A contribution to the archeology of Old Oyo, Ph.D. thesis, University of Ibadan, 1983.

[18] K. Adepegba, Contemporary Yoruba Wood Carving, (Ikorodu, Aramanda Creations, 2007).

[19] W. Abimbola, Lagbayi the Itinerant Wood Carver of Ojuwon in Rowland Abiodun, Henry John Drewal and John Pemberton, III (eds.), The Yoruba Artist, (Smithsonian Institution Press, Washington and London, 1993) 137-142.

[20] C. Adepegba, Nigerian arts: Its tradition and modern tendencies (Ibadan, Jodad, 1995).

[21] D. William, Art in Metal," in S. O. Biobaku (ed.), Sources of Yoruba History (Oxford Clarendon Press, 1973) 140-164.

[22] A. Opefeyitimi, The Oloje Panegyrics: An Index of Aesthetic and Power Determinant in Wood Carving," in Kalilu R. O. Rom (ed.), Power of Expression and Expression of Power in Yoruba Art, (Bidsol and Associates, Lagos) 20-39.

[23] Abiodun Rowland "The Future of African Art studies: An African Perspective," in African Art Studies: The state of the Discipline, (Smithsonian Institution Press, Washington and London, 1993) 65-89.

[24] R. Abiodun, H. J. Drewal and J. Pemberton III, Yoruba art and aesthetics (Zurich, Rietberg Museum, 1991)

[25] M. O. Areo and R. O. Rom Kalilu, Adire in South-western Nigeria: Geography of the centres, African Research Review: An International Multidisciplinary Journal, Ethiopia, Vol. 7 (2), Serial No. 29, April, 2013, 350-370

[26] G. B. Aremu (ed), Exhibition in honour of Oranyan the great (Maiden edition), 2012 